\title{
Mozambican immigrants to South Africa: Their xenophobia and discrimination experiences
}

\author{
Miriam Moagi ${ }^{1 *}$, Gail Wyatt ${ }^{2}$, Maboe Mokgobi ${ }^{3}$, Tamra Loeb $^{2}$, Muyu Zhang ${ }^{2}$ and Mashudu Davhana- \\ Maselesele 4 \\ ${ }^{1}$ Department of Nursing Science, Faculty of Health Sciences, University of Pretoria, Pretoria, South Africa \\ ${ }^{2}$ Department ofPsychiatry and Bio-behavioral Sciences, Semel Institute for Neuroscience and Human Behavior, Los \\ Angeles, CA, USA \\ ${ }^{3}$ Faculty of Social and Health Sciences, Monash South Africa, Roodepoort, South Africa ${ }^{4}$ North-West University, \\ Mahikeng, South Africa ${ }^{1}$ Corresponding author email: Miriam.Moagi@up.ac.za
}

\begin{abstract}
We explored Mozambican immigrants' lived experiences of xenophobia and discrimination in South Africa. Informants were 15 Mozambican immigrants (female $=7$, male $=8$ ) living in an informal settlement in Zandspruit, Gauteng Province. They completed open-ended written narratives on xenophobic and discriminatory experiences. Following thematic analysis, we identified three themes to characterise the Mozambican immigrants' experiences of xenophobia and discrimination: (i) abusive attitudes, (ii) ethnic discrimination, and (iii) scapegoating. The Mozambican immigrants' experiences of xenophobia and discrimination are consistent with findings from the extant international literature on ingroup/outgroup social strife with real or perceived scarcity of resources.
\end{abstract}

Keywords: attitudes, discrimination, immigrants, Mozambique, South Africa, xenophobia

\section{Introduction}

Xenophobia and discrimination against black immigrants to South Africa has been in the local and international news several times in the past decade (Bekker \& Carlton, 2010; Lovegrove, 2014; Solomon \& Kosaka, 2013). Xenophobia is defined as attitudes, prejudices and behaviour that reject, exclude and often demean a person, based on the perception that they are outsiders or foreigners to a community or society (Adjail \& Lazaridis, 2013). Xenophobic violence and discriminatory acts have their roots in race, ethnicity, gender, and geographical affiliations in the face of real or imagined scarcity of resources (Sebola, 2017), or group affiliation insecurity (Misago, 2015). Any human social attribute can be grounds for in-group and out-group membership, which in the face of competition for resources can result in hate crimes by "in-group" members against "out-group" others (Kinge 2016).

In societies with a history of racism and/or ethnocentrism, xenophobic and discriminatory attacks occur along racial/ethnic lines. South Africa is a case in point with its long history of racism dating back to the European colonial period (Kinge, 2016; Sebola 2017; Crush \& Ramachandran, 2014, 2008). Additionally, the country has a long history of ethnocentrism in which indigenous populations privileged their linguistic, cultural, and geographical identities; often with hostility against those of different cultural and linguistic background (Idehen \& Osaghae, 2015; Matsinhe, 2011). Within this context historic ethnocentrism could occur against black immigrants from other African countries with a different cultural linguistic heritage.

South Africa has attracted a sizeable influx of black Africans from other African countries seeking economic opportunities and/or human rights protections (Adeagbo, 2011; Adjai \& Lazaridis, 2013; Crush \& Pendleton, 2012). A large number of the immigrants are unskilled or semi-skilled and generally settle in the informal settlements near major cities such as Pretoria, Johannesburg, Cape Town, and Durban (Crush \& Ramachandran, 2014). South African informal settlements are comprised of poor families illegally occupying subserviced city council land, creating "a shanty town" of make-shift structures "built mostly from scrap material" (Housing Development Agency: HDA, 2013, p . 7). Resident South Africans in Informal settlements derogatively refer to Mozambican immigrants (and other black African immigrants to South Africa) as "kwerekwere", "Amakwere- 
kwere", or "Amagrigamba" (black people who cannot speak the regional local South African language). This designation can fuel hostilities towards immigrant blacks from neighbouring countries who do not speak the language of the South African region where they’ve settled (Solomon \& Kosaka, 2013).

To our knowledge, little research has been conducted on xenophobia and discriminatory attitudes towards Mozambican immigrants The Mozambican population is the largest foreign national population in regional Zandspruit, Gauteng Province of South Africa (Lovegrove, 2014). Mozambique and South Africa are neighbouring countries. Due to the arbitrariness of the territorial borders that the two countries inherited from the European colonial period, several cultural-linguistic communities, such as the Tsonga and Zulu cultural community territories, cross the national boundaries.

Mozambique is South Africa's largest trading partner, with South Africa mainly exporting goods to Mozambique. According to the World Bank (World Bank Data Team, 2018), South Africa is an upper middleincome country, while Mozambique is a low-income country In 2010, almost 70\% of the Mozambican population lived on/or less than US\$1.90 a day, compared to 16.6\% in South Africa. Thus, Mozambican immigrants come to South Africa expecting to find jobs that pay better salaries, good living conditions, and a society with a welcoming attitude. However, the immigrants may encounter xenophobia and discrimination by black South Africans, once their country of origin is known or if they speak a different language or dialect. The informal economy in South Africa relies on the cheap and easily exploitable labour of undocumented immigrants mostly from Mozambique, and other African countries. The migrants' willingness to work for low wages and to enter this informal economy is perceived as taking opportunities from South Africans, resulting in animosity between the two groups (Kinge, 2016).

We sought to explore the lived experiences of xenophobic and discriminatory attitudes towards Mozambicans. Our specific research question was: "What are the lived experiences of xenophobic and discriminatory attitudes towards Mozambican immigrants in the informal sector of South Africa"?

\section{Method}

\section{Research design}

We used an exploratory-descriptive qualitative research approach to explore the lived experiences of xenophobic and discriminatory attitudes towards Mozambican immigrants in an informal settlement in South Africa An exploratory-descriptive qualitative research approach is one aimed at understanding the phenomenon (i e xenophobia in the case of the current study) without imposing any theoretical lens. It was appropriate for the present study as the goal was to characterise xenophobia and discrimination experiences of Mozambican immigrants to South Africa.

\section{Participants and setting}

We sampled 15 Mozambican immigrants (female $=7$; age range $=22$ to 69 years) from the Zandspruit informal settlement in the Gauteng Province of South Africa. All 15 participants spoke isiTsonga (Shangaan). In addition, the immigrants also spoke one or both of English and isiZulu. Two of the informant immigrants self-reported to be undocumented. The immigrants had lived in South Africa for at least three months or longer.

\section{Procedure and data collection}

We obtained permission to conduct the study from the Institutional Review Board of the University of California, Los Angeles (UCLA) and the Human Sciences Research Council's Research Ethics Committee (HSRC-REC) (Ethical clearance numbers: UCLA IRB\#14-000712; HSRC-REC 3/22/10/14) . We informed participants of the purpose of the study and asked them to provide oral consent in lieu of written consent Interviews were conducted in a private room to promote privacy We ensured participants' confidentiality by using numbers to code responses instead of names.

The informant immigrants completed open-ended written narratives on their lived experiences of xenophobia and discriminatory attitudes in South Africa. After the 15 narrative interviews, we believe the data to have reached saturation. 


\section{Data analysis}

Data were analysed using Braun and Clarke's (2006) six stages of thematic analysis methods for recognising, examining, and recording themes within the data: familiarisation with the data, generating initial codes, searching for themes, reviewing themes, defining and naming themes, and producing the report The first listed author and an independent coder collaboratively identified the themes from the data analysis.

\section{Results}

Three themes emerged from the analysis namely: abusive attitudes, ethnocentric discrimination, and scapegoating. The results are substantiated by verbatim quotations (participant identifier codes are indicated in brackets).

\section{Theme 1: Abusive attitudes by local residents}

About four of the 15 Mozambican immigrants (26.7\%) perceived to have experienced abuse by South African citizens for being foreigners. The specific abuses included emotional, physical, and verbal abuse. For instance, some of the immigrants observed:

[We] hear people saying we must go back home to our countries as we do not belong to South Africa. [P\#12, male]

[They] they call immigrants "amakwerekwere" [P\#12, female]

... [and some locals] come and loot the shop saying we are taking their jobs, we are not voting, we do not have proper documents, they are suffering alone to keep the government in power. [P\#15, male]

...I don't have a husband now because South African people killed him because they accused him of being a thief. Now my children don $t$ have a father. [P\#2, female]

[We] live in fear, [as] many foreigners were tortured [and] burned alive, others were stabbed to death because they were [black] African immigrants, it was very traumatic as no one was helping us even the police came after a long time when an immigrant person is dead. [P\#4 male]

These findings on emotional, physical, and verbal abuse are similar those reported in several previous studies with different immigrant groups in South Africa (see for example Charman \& Piper, 2012; Kinge, 2016, Lovegrove, 2014; Misago, 2009; Morapedi, 2007).

\section{Theme 2: Immigrants are discriminated against}

A total of nine immigrants (60\%) reported to experience ethnic discrimination in accessing work and other human services. For instance, some of the immigrants made these observations:

\section{Denial of access to human and civic community services}

[We are denied access] to at clinics or hospitals of being "Lekwerekwere" [speakers of a foreign language] [our children are] called names and reminded that they are foreigners. [P\#6, female]

[Our children may not be] allowed to attend school because they were not... citizens. [P\#3, male]

It is difficult for us immigrants to get access to employment especially permanent job [because we are denied] South African identification document.[P\#10, male]

\section{Remuneration discrimination}

I worked for three months as a garden boy for a black man in Gauteng without pay. When that man was supposed to pay me my salary he said that he will not pay me because I am a foreigner and said to me that I can do whatever I want. [P\#8, male] 
I worked for a South African man, he promised me that I will get paid when I am done with my job,[after] instead of him paying me, he asked me for my documents, when I said I don $t$ have documents, he gave me a certain document saying I must sign it first for him to pay me. [P\#14, male]

I worked for a certain company [and] was paid less money and when I asked for an increase on my salary they tell me that foreigners do not qualify for a salary increase because they do not have proper documents. [P\#11, male]

\section{Deprivation of property rights}

I have lost a house and land in another area because I am an immigrant; I was told that I didn't vote, so if I want to own a house I must go back to my country. [P\#7, female]

My house that I bought from a South African citizen was taken away from me; I was told that I do not qualify to have a house because I am not a citizen of SA. [P\#9, female]

Although we participate in public protests with the locals, they reminded us that we are not citizens after getting concessions from their government. [P\#13, male]

The findings indicate immigrants to experience high levels of intolerance and hostility from South African informal settlement residents, as well as threats to their livelihoods and properties. These acts are contrary to the "New South Africa" built on inclusiveness and tolerance (Kinge, 2016). Undocumented immigrants are more likely to work full time, but their jobs are low paying, often below minimum wage, and unstable (Yoshikawa \& Kalil 2011). This psychological and emotional pressure can have a significant toll on the psychological and physical wellbeing of immigrant children (Chaudry, et al., 2010).

\section{Theme 3: Scapegoating for any problem faced by South Africans}

Two of the 15 immigrants (13.33\%) reported to be blamed for social evils bedevilling South Africa; including increased rates of HIV/AIDS, increased crime rate, and unemployment. For instance, the immigrants said:

... whenever there is a crime which has been committed within the community, immigrants are being blamed, and by the police [too]. they always use immigrants as scapegoat. [P\#5, male]

Immigrants [are accused] of bringing drugs in South Africa for taking jobs from South African citizens. [P\#1, female]

... During xenophobia [attacks], South African citizens were blaming immigrants [for] taking their jobs. [P\#1, female]

South African officials and the police (Chan, 2015) often mistreat Mozambicans. Due to their undocumented status, they are unable to report crimes, and the women and children are thus especially vulnerable to abuse and rape (Osman, 2009; Pretorius, 2004). Additionally, negative attitudes are fostered by the media, who make statements such as "migrants are flooding and swarming into South Africa", "illegals or "illegal foreigners" (Kinge 2016, p 38; Nyamnjoh, 2006; Tevera 2013) The media plays an important role in the shaping of views and attitudes towards immigrants (Adeagbo, 2013). Much of the negativity towards immigrants rests in their undocumented status.

\section{Implications for South Africa and it's immigration policies}

The United Nations High Commission for Refugees advocates for the humane treatment of asylum seekers, refugees, and (by extension) immigrant workers who also may be refugees (UNHCR, 2011). South Africa is signatory to this UNHCR instrument. Yet, xenophobia and discrimination towards immigrants makes South Africa one of the most migrant-unfriendly countries in the world (Crush \& Ramachandran, 2009). 
The wave of xenophobic attacks in South Africa against African immigrants has tarnished the country's image, both internationally and in the South African Development Community (SADC) region. African countries, including Nigeria and Namibia, have started expelling South African citizens in response to xenophobic attacks. Additionally, they no longer support South African businesses in their jurisdictions (Chen, 2015). Xenophobic violence has also damaged the South African economy which had previously attracted many foreign investors (Cordeur, 2015).

Xenophobic attacks and the poor response from the South African government have tarnished the country's image as a leading member of the African Union (Kinge, 2016; Matunhu, 2011). The South African government should provide for immigrant-friendly documentation processes so that those who are residents of informal settlements are protected from labour exploitation and other abuses Moreover, the media could host regular symposia to educate both South African and immigrant people of the rights of the immigrants under the law.

\section{Limitations of the study and suggestions for future research}

One study limitation includes the fact that it was carried out in one informal settlement only and with a small sample of informants. Findings may be different in different informal settlements and with a larger sample size. Moreover, the written narrative approach to data collection has the limitation to restrict the self-reporting of those with poorer written language. Future studies could utilise verbal interview approaches for richer data reporting..

\section{Conclusion}

Mozambican immigrants in Gauteng, Zandspruit informal settlement, South Africa, experience chronic xenophobia and discrimination. Black immigrant foreigners living in these settlements are traumatised and feel unsafe Mozambican immigrants have reported frustrations in acquiring the right documentation. Lack of proper documentation increases vulnerability to exploitation and crime. In South Africa, xenophobia has damaged the informal employment sector, resulting in higher unemployment rates due to the displacement and burning of immigrant shops that employed South Africans (Sanchez, 2015). Tourism from African countries has also decreased

\section{Endnote}

${ }^{1}$ Author affiliation at date of article accepted for publication.

\section{References}

Adeagbo, O. A. (2013). 'We are not criminals, we are just victims of circumstances': An exploration of experiences of Nigerian immigrants' men that married South African women in Johannesburg. National Identities, 15(3), 277-296. https://doi.org/10.1080/14608944.2013.780016

Adjail, C. \& Lazaridis, G. (2013). Migration, xenophobia, and new racism in post-apartheid South Africa. The International Journal of Social Sciences (Islamabad), 1(1), 192-205.

Bekker, S. \& Carlton, D. (2010). Racism, xenophobia and ethnic conflict. Natal, SA: Crede.

Braun, V. \& Clarke, V. (2006). Using thematic analysis in psychology. Qualitative Research in Psychology, 3(2), 77-101. https://doi. org/10.1191/1478088706qp063oa

Chan, S. (2015, November 11). South African court sentences 8 ex-policemen in immigrant's murder. The New York Times. Retrieved from https://www.nytimes.com/2015/11/12/world/africa/south-africa-policemurder-mozambique-immigrant html 
Charman, A. \& Piper, L . (2012). Xenophobia, criminality and violent entrepreneurship: Violence against Somali shopkeepers in Delft South, Cape Town, South Africa South African Review of Sociology, 43(3), 81105. https://doi.org/10.1080/21528586.2012.727550

Chaudry, A., Capps, R., Pedroza, J., Castaneda, R., Santos, R., \& Scott, M. (2010). Facing our future: Children in the aftermath of immigrant enforcement Washington, DC: Urban Institute.

Chen, L. (2015). Regressive Effect of Xenophobia to South Africa's economy growth. Retrieved from http://www. nepadbusinessfoundation org/index php/membership/member-stories/512-press-release-5

Crush, J, \& Ramachandran, S (2009) Xenophobia, International Migration and Human Development (No. HDRP-2009- 47). Human Development Report Office (HDRO), United Nations Development Programme (UNDP).

Crush, J, \& Ramachandran, S. (2010). Xenophobia, international migration and development. Journal of Human Development and Capabilities, 11(2), 209-228. https://doi.org/10.1080/19452821003677327

Crush, J, \& Ramachandran, S. (2014). Xenophobic violence in South Africa: Denialism, minimalist, realism (Report no. 66). Cape Town: Southern African Migration Programme.

Crush, J., Ramachandran, S, \& Pendleton, W. (2013). Soft targets: Xenophobia, public violence and changing attitudes to migrants in South Africa after May 2008. Retrieved from http://samponlineorg/wpcontent/uploads/2016/10/Acrobat64.pdf

Housing Development Agency (2013). Informal settlements in South Africa. HDA: Johannesburg, South Africa.

Idehen, R. O., \& Osaghae, F. S. (2015). Xenophobia in South Africa: Re-thinking the Nigeria foreign policy of Afrocentrism. African Research Review, 9(4), 78-91. https://doi.org/10.4314/afrrev.v9i4.7

Kinge, G. T. (2016). International dimensions of xenophobic attacks on foreign nationals in South Africa (Doctoral dissertation) North-West University, Mafikeng.

Landau, L. B, Segatti, A, \& Misago, J. P. (2013). Planning and participation in cities that move: Identifying obstacles to municipal mobility management Public Administration and Development, 33(2), 113-124. https://doi.org/10.1002/pad.1642

Le Cordeur, M, (2015, April 14). Xenophobic attacks will hurt foreign investors' confidence-economist Fin24. Retrieved from https://www.fin24.com/Economy/Xenophobic-attacks- will-hurt-foreign-investor-confidenceeconomist-20150414

Lovegrove, K S (2014). The construction of identity in a Mozambican community: Reflections on xenophobia in South Africa (Doctoral dissertation) UNISA, Pretoria.

Matsinhe, D. (2011). Africa's fear of itself: The ideology of Makwerekwere in South Africa Third World Quarterly, 32(2), 295-313. https://doi.org/10.1080/01436597.2011.56 0470

Matunhu, J. (2011). Re-visiting the May 2008 xenophobic attacks in South Africa. African Journal of Criminology and Justice Studies: AJCJS, 5(1/2), 95' 
Misago, J. P. (2009). Xenophobic violence in South Africa: Reflections on causal factors and implications. Policy Studies Bulletin at CPS, 10(3), 3-8.

Misago, J. P. (2015, March 3). Xenophobic violence in South Africa: Reflections on trends, explanations and responses . Retrieved from https://www.wits.ac.za/media/news-migration/files/JPMisagoMarch15.pdf

Morapedi, W G (2007) Post-liberation xenophobia in Southern Africa: The case of the influx of undocumented Zimbabwean immigrants into Botswana, c. 1995-2004. Journal of Contemporary African Studies, 25(2), 229-250. https://doi.org/10.1080/02589000701396330

Nyamnjoh, F. B. (2006). Insiders and Outsiders: Citizenship and Xenophobia in Contemporary Southern Africa London \& New York: CODESRIA Books in association with Zed Books

Osman, R (2009) The Phenomenon of Xenophobia as Experienced by Immigrant Learners on Inner City Schools of Johannesburg (Master's Thesis), UNISA, Pretoria.

Pretorius, R (2004) Political refugees as victims of prejudice, discrimination and abuse Acta Criminologica: Southern African Journal of Criminology, 17(2), 131-142.

Sanchez, D. (2015). What's the Economic Impact of South African Xenophobic attacks? Retrieved from https://moguldom com/94557/economic-impact-of-south-african-xenophobic-attacks/

Sebola, M. P. (2017). Xenophobic attitudes against immigrants and cheap political talks: Sitting time bombs and explosives in South Africa. Bangladesh e-Journal of Sociology, 14(1), 89-103.

http://www.bangladeshsociology.org/14.1-6.pdf

Solomon, H , \& Kosaka, H (2014) Xenophobia in South Africa: Reflections, narratives and recommendations South African Peace and Security Studies, 2(2), 5-29.

Tevera, D (2013) African migrants, xenophobia and urban violence in post-apartheid South Africa Alter Spe Edi, 7, 9-26.

UNHCR. (2011). Handbook and guidelines on procedures and criteria for determining refugee status UNHCR: Geneva, Switzerland.

World Bank Data Team. (2017). New Country Classifications by Income Level.

https://blogs.worldbank.org/opendata/new-country-classifications-income-level-2017-2018.

Yoshikawa, H, \& Kalil, A. (2011). The effects of parental undocumented status on the developmental contexts of young children in immigrant families. Child Development Perspectives, 5(4), 291-297.

https://doi.org/10.1111/j.1750-8606.2011.00204.x 